Article

\title{
Industrial Waste Materials as Alternative Fillers in Asphalt Mixtures
}

\author{
Catalina Dimulescu ${ }^{1}$ and Adrian Burlacu ${ }^{2, *(D)}$ \\ 1 National Road Infrastructure Management Company, Center for Road Technical Studies and Informatics, \\ 061127 Bucharest, Romania; catalina.dimulescu@cestrin.ro \\ 2 Department of Roads, Railways and Construction Materials, Faculty of Railways, Roads and Bridges, \\ Technical University of Civil Engineering of Bucharest, 020396 Bucharest, Romania \\ * Correspondence: adrian.burlacu@utcb.ro
}

Citation: Dimulescu, C.; Burlacu, A. Industrial Waste Materials as Alternative Fillers in Asphalt Mixtures. Sustainability 2021, 13, 8068 https://doi.org/10.3390/su13148068

Academic Editors: Antonio D'Andrea and Beatriz Tovar de la Fe

Received: 11 May 2021

Accepted: 13 July 2021

Published: 20 July 2021

Publisher's Note: MDPI stays neutral with regard to jurisdictional claims in published maps and institutional affiliations.

Copyright: (c) 2021 by the authors. Licensee MDPI, Basel, Switzerland. This article is an open access article distributed under the terms and conditions of the Creative Commons Attribution (CC BY) license (https:// creativecommons.org/licenses/by/ $4.0 /)$.

\begin{abstract}
One important role in asphalt mixture performances is represented by the filler content and characteristics. This research aims to assess the potential usage of industrial waste powders as replacers of the standard limestone filler in asphalt mixture composition. First of all, an SEM and EDX analysis was carried out to figure whether this industrial waste can be used in asphalt mixture composition by comparing the results of the industrial wastes with the properties of the standard filler. After a chemical evaluation, laboratory investigations were carried out to characterize the materials in terms of geometrical and physical properties. The research study involved sixteen dosages of limestone filler with four different types of industrial waste powders in different percentages used. The results obtained from laboratory testing suggested that the inclusion of industrial wastes in the manufacture of asphaltic mixtures may have benefits for the construction industry, the waste management sector, and also for the environment.
\end{abstract}

Keywords: sustainability; industrial wastes; recycling; asphalt mixture; filler

\section{Introduction}

Due to the modernization of the construction industry, the use of wastes is an attractive trend with high potential for many highway researchers, with cleaner manufacturing and viable development as the chief aim. For these researchers, the purpose of their work is primarily to ensure economic, safe, smooth, and sustainable roads in order to carry the expected loads. Under these circumstances, an increased interest has been given toward the finding of road materials that could reduce the deterioration of the structure and increase the functioning of asphalt pavements. The filler is one of the constituents of asphalt mixtures, and it contributes greatly to their behavior and properties, especially the effects of aggregate binding.

Asphalt mixtures are made from bitumen, mineral aggregates, filler, and additives (if necessary). The filler is a very fine aggregate that is obtained from industrial processes or natural rocks. Limestone powder represents the most commonly used filler. The fillers may come in different types of powder forms, with the maximum particle size of $0.063 \mathrm{~mm}$ according to EN 13043:2003 [1], and their addition in bituminous or hydraulic mixtures determines specific characteristics. Fillers are impactful in the manufacture of asphalt mixtures, as they can significantly influence the physical and mechanical properties of the mixtures [2-4]. Although fillers are extensively used in the manufacture of asphalt mixtures, proposing a general classification that describes all the functions done by the fillers used in asphalt mixtures is still challenging $[5,6]$. The fillers represent the finest part of the aggregate structure of an asphalt mixture, completing the granulometry, thus contributing to the reduction of the air voids in the mixture. It majorly functions as an inert constituent that occupies the voids in between the aggregates in the mix and gives rise to a denser and impermeable mix. Several experimental applications and studies have 
pointed out that fillers can contribute to the decrease of the asphalt mixtures' thermal sensitivity or the betterment of the mechanical properties of the mastic that covers the coarse aggregates $[7,8]$. The fillers must have certain physical and chemical properties that allow for compatibility between the aggregates and the bituminous binder, at the same time guaranteeing a good rheological behavior of the mixture at the different temperatures encountered throughout the life of the asphalt mixture layer [9-11].

The relation between the filler and bitumen can be described as three main mechanisms: (a) volume filling, (b) particle structuralization, and (c) physical-chemical interactions [12]. Usually, the first two mechanisms facilitate mechanical reinforcement. The physical-chemical interactions consist of the adsorption process of the asphalt binder polar fractions onto the filler surface's active spots by the van der Waals forces. The last mechanism is related to the filler's chemical composition, hydrophobicity, surface charge, and surface area.

For the filler to play an effective role, it should possess the proper properties in terms of granulometry, the form and surface area, and also the proper mineral composition [13]. During the formation of the bitumen-filler bonding, the bitumen's polar molecules (asphaltenes and polar aromatics with hetero atoms) are largely localized on the filler particles' surface, thereby producing a particular interphase region, also called the transition zone [14]. The bitumen-filler bond strength excogitates how good the bond is maintained in the presence of water. Hence, the interactions between the two components might affect the asphalt mixture's frost and water resistance. When the asphalt mixture is exposed to moisture and water, the boundary bitumen film's organized nanostructure may be interrupted because the water molecules can act with the asphaltenes and polar aromatics.

For filler particles that are finer, the bitumen film thickness can affect the resulting mastic's viscosity and therefore act upon the bitumen mixes' performance against the action of different types of load [15]. The performance of bituminous mixtures also depends on the filler's physical, mineralogical, and morphological properties, its physical-chemical interaction with the bitumen, and its concentration in the mixture [16-19]. The mastic behavior is determined by the filler type and its content, and this can have a bearing on the intermixture and the compaction of the bituminous mixtures [20,21]. Selecting the appropriate type of filler is an important action in the process of designing the asphalt mixture [22].

At present, there is a serious global issue caused by environmental pollution from waste products, and it has become a threat to sustainable development policy. It is well known that industrial wastes pose environmental and human health hazards, and combined with an intensive exploitation of natural resources, they can determine permanent alterations in the natural environment, such as disturbances in the existing ecosystem, groundwater level, and vegetation degradation [23].

A new approach for pavement engineering production has emerged from the studies and laboratory tests that investigated a wide range of new materials in the composition of asphaltic mixtures such as byproducts and industrial waste materials during the last 20 years. From an environmental viewpoint, the reuse of various waste materials reduces the space for authorized landfills and deposits, allowing for an economy of natural resources. Moreover, from an economic viewpoint, the reuse of various industrial waste materials and byproducts instead of still expensive new materials represents a more attractive solution. For example, fly ash is a bulky and heavy powder, making the transport of the material very expensive. It costs between 0.10 and $0.15 \mathrm{USD} / \mathrm{ton} / \mathrm{mile}$ to transport fly ash by a pneumatically loaded trailer truck. If improperly disposed, most of the industrial wastes might give rise to the interruption of ecological cycles, respiratory issues, and soil and water pollution.

In practice, a substantial consumption of natural resources, as well as bitumen and mineral aggregates, and the discharge of unsafe emissions into the air are linked to the building of road structures. However, several waste materials have been used as additives 
in aggregate replacement, concretes, and mortars. The use of waste powder as filler in asphalt mixtures has been trending in the scientific world in the last ten years.

Several research reports dealing with the investigation of potential waste materials able to act as traditional filler materials have been presented in the literature, including fly ash and slag [24], recycled concrete powder [25], cement kiln dust [26], waste glass [27], brick powder [28], rice husk ash [29], coal waste powder [30], oil shale [31], waste bleaching clay [32], paper industry wastes [33], recycled waste lime [34], phosphate waste filler [35], municipal solid waste incineration ash [36-38], baghouse fines [39], oil shale fly ash [40], waste ceramic materials [41], waste marble materials [42-45], and waste tires [46,47]. It has also been reported that the properties of bituminous mastic are closely related to the type and percentage of fillers in the asphalt mix [48]. The chemical composition of the filler significantly influences the behavior of asphalt mixtures over their service period as well $[49,50]$.

Large areas of land have become completely unusable because of the storage of industrial wastes. In Romania, a surface of almost 15,500 ha is occupied by various wastes, namely industrial waste tailing from the mining industry, flotation dumps that result from the processing of ferrous and non-ferrous deposits, fly ash and slag from power plants, and dumps from the steel and chemical industry. Thoughtful utilization of these byproducts might give rise to many economic and environmental benefits by cutting down the environmental costs that power and thermal plants incur for deposited waste.

This research aims to investigate the usage of four different waste materials (soda sludge, calcium sulfate, fly ash with lime, and fly ash) as fillers in asphalt mixtures while utilizing limestone filler as the control material. Characterization is carried out for the materials in terms of their chemical, geometrical, and physical properties, and their interaction with bitumen. In particular, the physical and mechanical properties of the asphalt mixtures obtained are used to evaluate the suitability of these waste materials for asphalt mixture production.

\section{Materials and Methods}

The waste materials to be studied here represent industrial wastes from soda production and thermal power plants. Their chemical and morphological properties were used to characterize the materials, and the materials were assessed in terms of their physical and mechanical properties. These industrial waste powders are compared to limestone powder, which is usually the most used material in Romania.

This research stage evaluated five possible types of mineral powders that can be used as an additive in asphalt mixtures. The scope of utilization of these industrial waste powders is for the valorization of the wastes resulting from different industries (ferrous metallurgy, energetic, etc.) as raw material or as an addition to asphalt mixture manufacturing.

\subsection{Materials}

\subsubsection{Limestone Filler}

The first filler analyzed is the traditional filler used in asphalt mixture composition in Romania, namely limestone filler. This material resulted from the fine grinding of limestone, and in this study, it was sourced from a local Holcim stone factory. It is very well known that limestone filler contains a high degree of calcium carbonate (minimum 90\%).

\subsubsection{Soda Sludge Powder}

One of the raw materials used in the experiments is the soda sludge resulting from the soda production process from Govora. It is discharged and subjected to primary decantation in soda sludge stockpiles (also called settling ponds). The soda sludge is collected in the soda sludge tank, and the soda sludge settling takes place; the cleared water (bathing limes) received by the exhaust system from the reverse probes and the drainage 
systems are evacuated into the retention basins, and then the water is discharged through the drainage channel of conventionally clean water.

The amount of soda sludge pumped for storage in the Govora area is about $500 \mathrm{~m}^{3} / \mathrm{h}$, when the plant operates normally. The surface occupied by the site of the bottles occupies about 146 ha and is bordered by a contour dam with a height of $2.5 \mathrm{~m}$ and a length of $5 \mathrm{~km}$; the dam is made of local materials (sand and gravel) and a terrace with a waterproof clay mask inside. Currently, the complex of soda sludge bottles storage (tailings ponds) consists of 6 units.

In the dry state, the soda sludge is a solid in the form of a powder, odorless, white, or almost white. This material is not explosive or combustible. Short-term exposure to dry powder poses either very little or no danger.

The sludge must be handled with care, using appropriate control measures. It may accumulate or adhere to the walls of the space in which it is stored and may release or collapse spontaneously and unexpectedly. In order to prevent sinking or suffocation, it is forbidden to enter in the storage space (such as a silo, tank, truck tank, or material storage container).

The production dumps in the Govora area cover 55 hectares, and the decantation heaps, where the soda sludge from the production process is stored, cover 160 hectares.

\subsubsection{Calcium Sulfate Powder}

Another type of industrial wastes powder is represented by the calcium sulfate filler. Calcium sulfate is formed by the chemical reaction between limestone filler $\left(\mathrm{CaCO}_{3}\right)$ and sulfur dioxide $\left(\mathrm{SO}_{2}\right)$ gas generated by burning energy coal. Following the chemical analysis, traces of ash and other chemical elements can be highlighted. At temperatures above $1450{ }^{\circ} \mathrm{C}$, calcium sulfate decomposes into calcium oxide (CaO) and sulfur dioxide $\left(\mathrm{SO}_{2}\right)$.

In the dry state, calcium sulfate is a solid, odorless, white, or almost white powder. This material is not explosive or combustible. Short-term exposure to dry powder poses either very little or no danger. Calcium sulphate is handled with care using appropriate control measures. It may accumulate or adhere to the walls of the space in which it is stored and may release or collapse spontaneously and unexpectedly. This product may react with water, resulting in a slight release of heat, depending on the amount of limestone (calcium oxide) present.

\subsubsection{Fly Ash Powder}

It is very well known that fly ash is the main solid industrial waste obtained from a coal-fired thermal power plant. It has been utilized easily in the construction materials industry. The selected fly ash is from a local manufacturer, i.e., a Govora factory.

Thermal power plants fly ash powder are unanimously classified as industrial waste with severe ecological impact. Fly ash powder is a particulate material produced from the combustion of coal in thermal power plants. The huge production of fly ash is leading to its disposal problems, and hence methods are being studied for its use/disposal. Fly ash is a super fine material; the particle sizes average 45 microns in diameter. The smallest particles can be just 10 microns thick. This helps to give asphalt mixture its fine, powdery texture, which is what makes it a good bonding agent when added to aggregates and bitumen.

These particles are usually spherical in shape and have a glassy texture when viewed under a microscope. The color of fly ash can differ depending on whether other chemicals and minerals are present. Lime particles in fly ash give it a lighter color, whereas iron gives the ash a brown hue. Fly ash that is dark grey in color-which can be almost black-is usually caused by unburned coal in the power station furnace.

The ash is not volatile but can become airborne through drafts or during handling. Stored directly on the ground, the fly ash can enter the soil through rainwater and contaminate groundwater over time. 
Energy installations, especially thermal power plants that use coal as fuel, can influence the environment in a way that sometimes leads to affecting the ecological balance of the areas in which they are located, as they have a complex impact on all environmental factors in their vicinity (atmosphere, water, soil, flora and fauna, food and habitat). Thus, the energy sector is considered as the main source of pollution.

\subsubsection{Fly Ash with $10 \%$ Lime Powder}

Most research deals with and explains the hardening properties of hydraulic ash, using general indices of hydraulic activity, determined by single or combined mechanical, physical, and chemical methods. Of the many substances used to activate the ash, the addition of $\mathrm{CaO}$ proved to be the most effective, being superior both in effect and economically to the addition of cement, because it creates a basic environment in the ash-water activator system, which triggers chemical reactions underlying the resistance structure.

The reactions between the fly ash components are characterized by $\mathrm{SiO}_{2}, \mathrm{Al}_{2} \mathrm{O}_{3}, \mathrm{Fe}_{2} \mathrm{O}_{3}$, and $\mathrm{CaO}$. $\mathrm{CaO}$ ash activation depends on both the type of ash and the quality and amount of $\mathrm{Ca}(\mathrm{OH})_{2}$ used. For silico-aluminous and aluminosilicate ashes characterized by the sum of $\% \mathrm{SiO}_{2}+\% \mathrm{Al}_{2} \mathrm{O}_{3}+\% \mathrm{Fe}_{2} \mathrm{O}_{3}>70 \%$, the activity is efficient, while for calcium and sulfo-calcium ashes the effect of the interaction with lime is practically insignificant.

\subsection{Laboratory Experiments}

An experimental laboratory program was established to investigate the chemical and also the physical properties of the fillers to ensure they comply with the international standard [1]. Moreover, the experimental program included other complementary tests as well.

\subsubsection{Particle Shape}

Using scanning electron microscopy (SEM) technique, both natural filler and soda sludge industrial waste material were analyzed. This evaluation allowed for the examination of the particles morphology and the measurement of their average size, using the SU8230 SEM (Hitachi High-Technologies Corporation, Japan).

\subsubsection{Particle Size Distribution}

All materials were tested by the method specified in SR EN 933-10:2009 [48] using air-jet sieving for the evaluation of the particle size distribution of the fillers by mass weight, up to $2 \mathrm{~mm}$ nominal size. Test sieves had a round frame of $200 \mathrm{~mm}$ nominal diameter and square aperture sizes of $0.063 \mathrm{~mm}, 0.125 \mathrm{~mm}$, and $2 \mathrm{~mm}$. The air jet sieving apparatus had a pressure difference of $(3.0 \pm 0.5) \mathrm{kPa}$ across the sieve during the test procedure. The mass obtained on each sieve was calculated as the percentage of the original dry mass $\left(\mathrm{M}_{1}\right)$, rounded to the nearest whole number.

\subsubsection{Water Content}

All the materials has water content $(\mathrm{w})$, and this was determined using the methodology according to SR EN 1097-5:2008 [51]. Specimens of natural and industrial waste fillers were evaluated by weighing the wet mass and the mass after their drying in a ventilated oven, which is thermostatically controlled (a temperature of $110 \pm 5^{\circ} \mathrm{C}$ ). The value of the water content $(\mathrm{w})$ is represented as a percentage of the mass of the dry test portion, in accordance with the following equation:

$$
\mathrm{w}=\frac{\mathrm{M}_{1}-\mathrm{M}_{3}}{\mathrm{M}_{3}} * 100
$$

where

$\mathrm{M}_{1}$-mass of test portion, in grams;

$\mathrm{M}_{3}$-dried test portion (constant mass), in grams. 


\subsubsection{Particle Density}

The particle density of the fillers (SG) was determined by the pycnometer method according to the method detailed in SR EN 1097-7:2001 [52]. Three separate test specimens for each evaluated powder were used, and the calibration of the pycnometers was performed involving a liquid with a known density. Equation (2) was applied to calculate the particle density of all the fillers, in grams per cubic meter:

$$
\rho_{\mathrm{f}}=\frac{\mathrm{m}_{1}-\mathrm{m}_{0}}{\mathrm{~V}-\frac{\mathrm{m}_{2}-\mathrm{m}_{1}}{\rho_{1}}}
$$

where:

$\mathrm{m}_{0}$ - the mass of the empty pycnometer with stopper, in grams;

$\mathrm{m}_{1}$-the mass of the pycnometer with the filler test portion, in grams;

$\mathrm{m}_{2}$-the mass of the pycnometer with the filler test portion, topped up with liquid, in grams;

V-the volume of the pycnometer, in milliliters;

$\rho_{1}$-the density of the liquid at $25^{\circ} \mathrm{C}$, in grams per cubic meter.

$\rho_{\mathrm{f}}$-the particle density of the filler at $25^{\circ} \mathrm{C}$, in grams per cubic meter.

\subsubsection{Methlene Blue Value}

With the purpose to evaluate the presence of damaging components, especially the clay minerals, the methylene blue value of the fillers $\left(\mathrm{MB}_{\mathrm{F}}\right)$ was tested by the method described in SR EN 933-9+A1:2013 [53]. Increments of methylene blue solution were added consecutively in a suspension of the test portion in water. After each addition of solution, the adsorption of dye solution by the test portion was checked by executing a stain (tested on filter paper) with the purpose to detect the presence of free dye. After confirmation, the value was calculated with the following equation (3) and expressed as grams of dye adsorbed per kilogram of the size fraction tested $(0 / 0.125 \mathrm{~mm}$ fraction):

$$
\mathrm{MB}=\frac{\mathrm{V}_{1}}{\mathrm{M}_{1}} * 10
$$

where:

$\mathrm{M}_{1}$-mass of the test portion, in grams;

$\mathrm{V}_{1}$ - total volume of dye solution injected, in milliliters.

\subsubsection{Voids of Dry Compacted Filler}

The procedure for determining the voids of dry compacted filler was done using the Ridgen method. It was utilized for finding the bitumen carrying capacity of natural and artificial filler [54]. The percentage of air void represents the volume of air filler space in the filler; this is expressed as a percentage of the total filler volume after compaction. The height of the compacted filler bed was then used to determine the volume of the compacted filler. Using the particle density of the compacted filler, it is possible to calculate the air void content of the compacted filler.

We calculate the voids of the fillers as the mean of the three determinations from the individual values of $\mathrm{m}_{2}$ and $\mathrm{h}$ with an accuracy of $0.1 \%$, in accordance with Equation (4):

$$
\mathrm{V}=\left(1-\frac{4 * 10^{3} * \mathrm{~m}_{2}}{\pi * \alpha^{2} * \rho_{\mathrm{f}} * \mathrm{~h}}\right) \times 100
$$

where:

$\mathrm{V}$-the voids, in percent;

$\mathrm{m}_{2}$ - the mass of the compacted filler, in grams;

$\alpha$-the inner diameter of the dropping block cylinder, in millimeters;

$\rho_{\mathrm{f}}$-the particle density of the filler, in megagrams per cubic meter; 
$\mathrm{h}$ — the height of the compressed filler, in millimeters.

\subsubsection{Delta Ring and Ball}

The delta ring and ball $\left(\Delta \mathrm{T}_{\mathrm{R} \& \mathrm{~B}}\right)$ value represents the difference between the softening point of the mastic and the bitumen. The experimental test defined in the SR EN 14272:2007 [55] was conducted to determine the softening point of the bitumen and bituminous binders, which was found to be in the range of $28-150{ }^{\circ} \mathrm{C}$. The test method was also carried out according to SR EN 13179-1:2013 [56], which describes the procedure used for evaluating the stiffening impact of the filler aggregate if it is mixed with bitumen.

\subsubsection{Blaine Specific Surface Area}

The test method describes how to find the fineness of the powder material, using the Blaine method, specifically in terms of the specific surface evinced as the total surface area of powder (square centimeters per gram) [57]. It is highly well known that this test method is known to work for measuring the fineness of cement, and that the relative instead of absolute fineness values are obtained. The specific surface values were calculated using the following Equation (5):

$$
\mathrm{S}=\frac{\mathrm{S}_{\mathrm{s}} \sqrt{\mathrm{T}}}{\sqrt{\mathrm{T}_{\mathrm{s}}}}
$$

where:

S- the specific surface of the test sample, in $\mathrm{m}^{2} / \mathrm{kg}$;

$\mathrm{S}_{\mathrm{s}}$ - the specific surface of the standard sample used in calibration of the apparatus, in $\mathrm{m}^{2} / \mathrm{kg}$;

T-measured time interval, in seconds, of manometer drop for test sample;

$\mathrm{T}_{\mathrm{S}}$ - measured time interval, in seconds, of manometer drop for standard sample used in calibration of the apparatus.

\section{Results and Discussion}

\subsection{Morphological and Chemical Ccharacteristics}

Figures 1 and 2 present SEM micrographs of the limestone filler (standard) and soda sludge filler (industrial waste), respectively. The presence of agglomerated, fairly irregular particles of about $0.1-0.2 \mu \mathrm{m}$ with a relatively dense structure was noticed for both investigated materials, which is in a good agreement with [58-60].

The EDX analysis revealed the presence, in various proportions, of $\mathrm{Ca}, \mathrm{O}, \mathrm{Si}, \mathrm{Mg}$, and $\mathrm{Cl}$ in limestone filler and of $\mathrm{Ca}, \mathrm{O}, \mathrm{Al}, \mathrm{Mg}, \mathrm{S}, \mathrm{Si}$, and $\mathrm{Cl}$ in soda sludge filler, as shown in Figure $3 a, b$, respectively. 


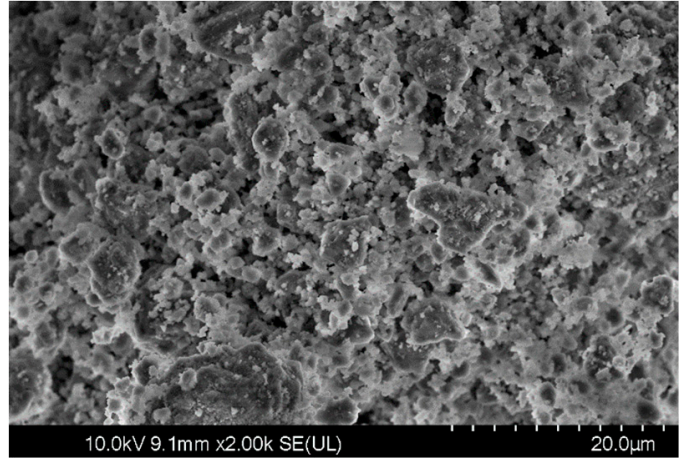

(a)

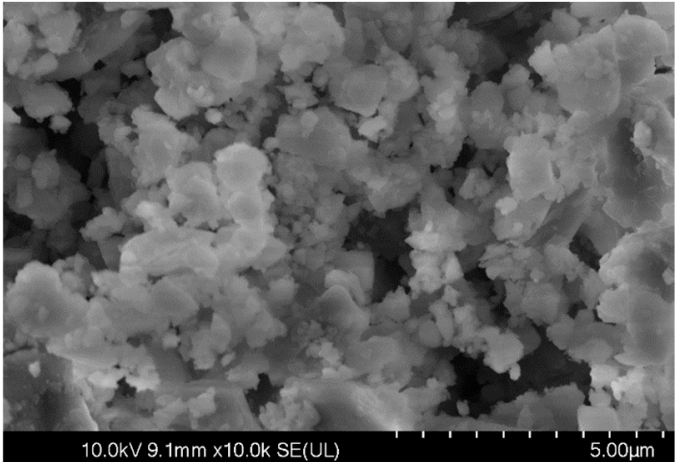

(b)

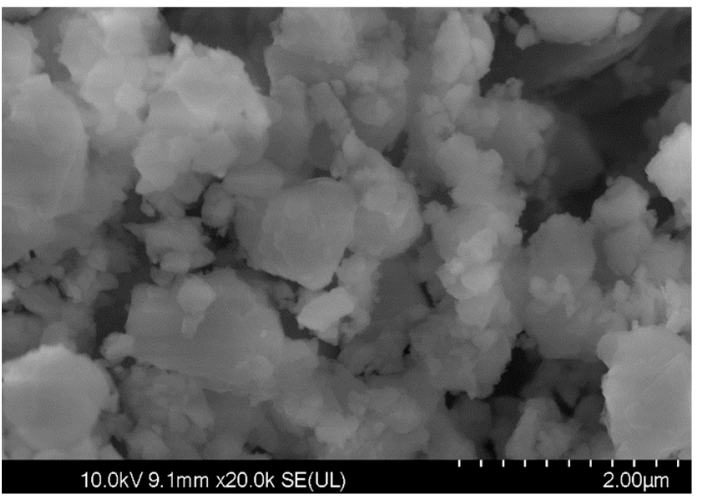

(c)

Figure 1. SEM micrographs of limestone filler, recorded at different magnifications: $2000 \times(\mathbf{a}) ; 10,000 \times(\mathbf{b}) ; 20,000 \times(\mathbf{c})$.

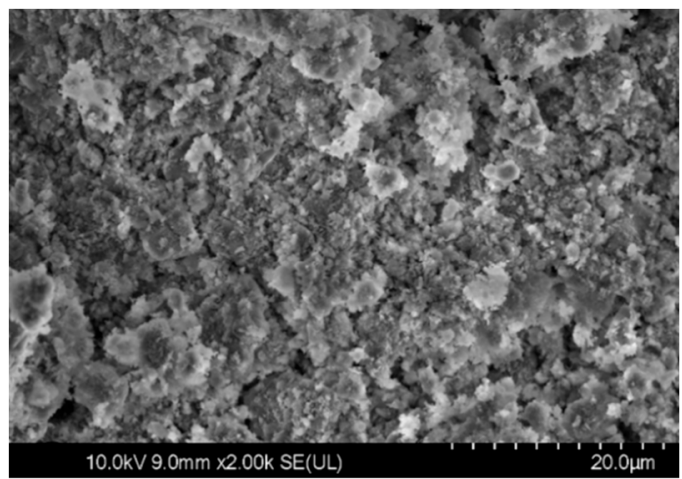

(a)

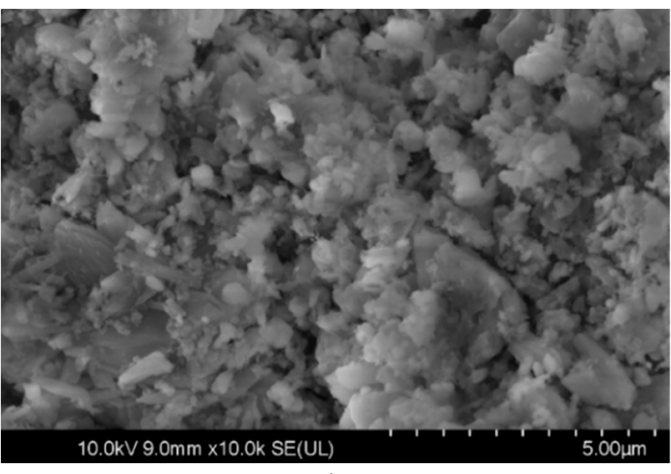

(b)

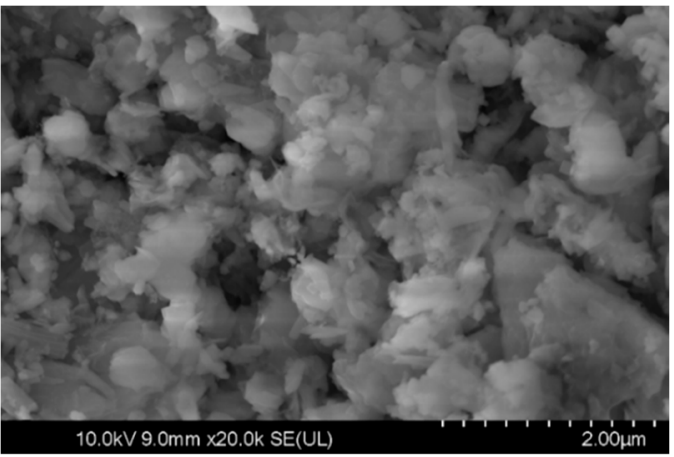

(c)

Figure 2. SEM micrographs of soda sludge filler, recorded at different magnifications: $2000 \times(\mathbf{a}) ; 10,000 \times(\mathbf{b}) ; 20,000 \times(\mathbf{c})$. 


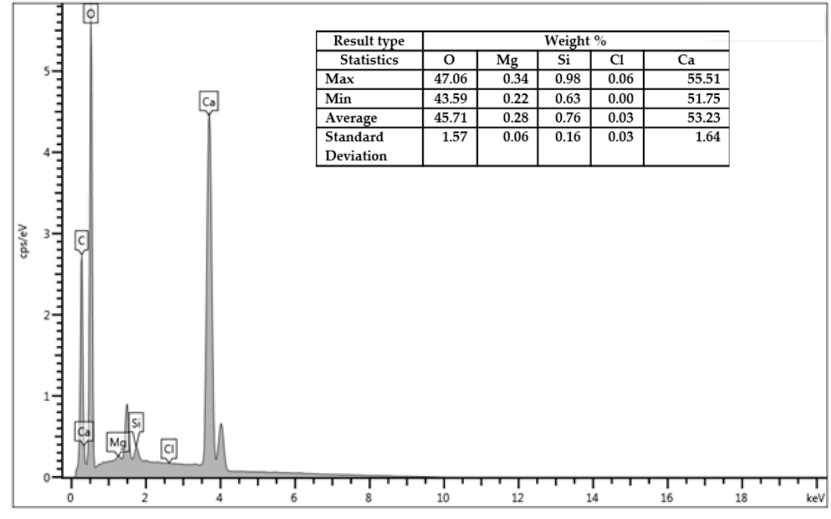

(a)

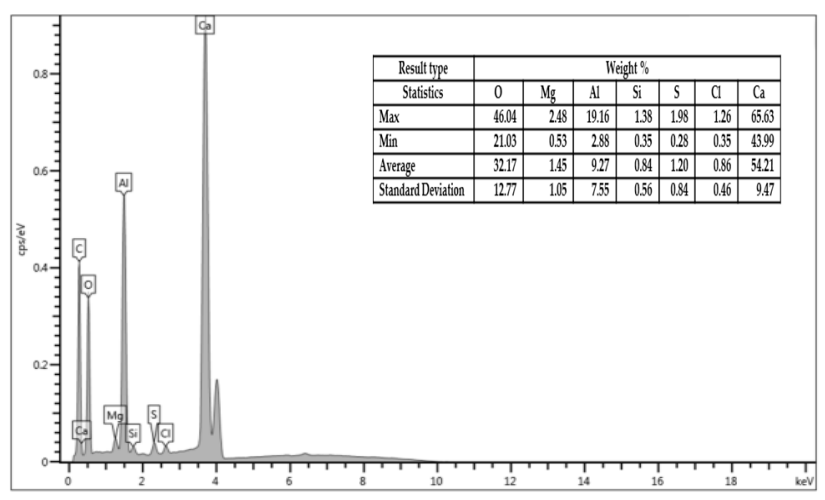

(b)

Figure 3. EDX analysis of (a) limestone filler and (b) soda sludge filler. Inset: the corresponding EDX elemental composition.

Average weight percentages of $\approx 45.7 \% \mathrm{O}$ and $\approx 53.2 \%$ Ca in the case of limestone filler and of about $32.17 \% \mathrm{O}$ and $54.2 \% \mathrm{Ca}$ for the soda sludge filler were found, suggesting the presence of mixed $\mathrm{Si}$ and $\mathrm{Mg}$ oxides associated with $\mathrm{CaSO}_{4}$ in the filler composition. The small amount of the $\mathrm{Cl}$ element might have originated in some impurities that remained from the synthesis procedures. The spatial distribution profiles for the main elemental components are presented in Figures 4 and 5 for the limestone filler and soda sludge filler, respectively.

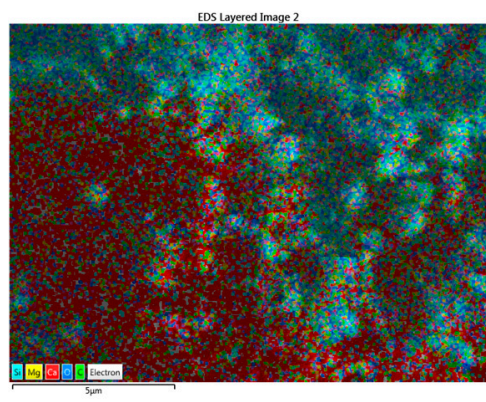

(a)

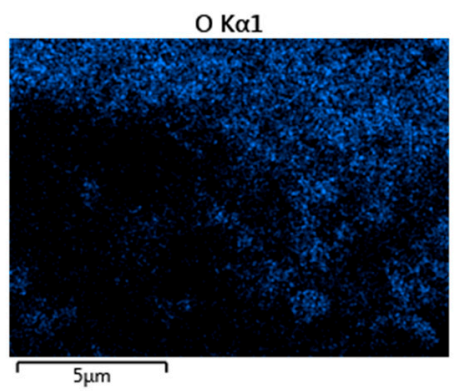

(d)

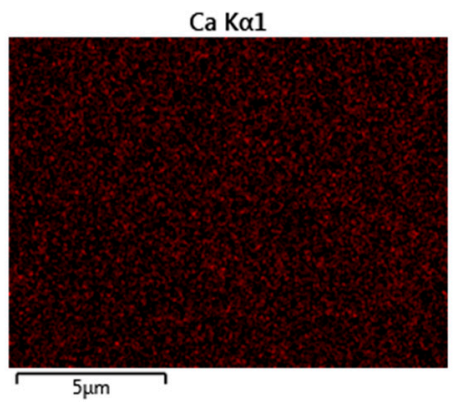

(b)

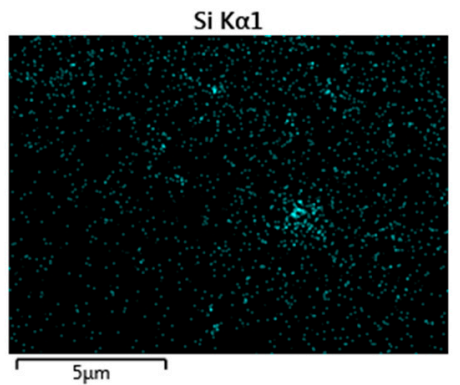

(e)

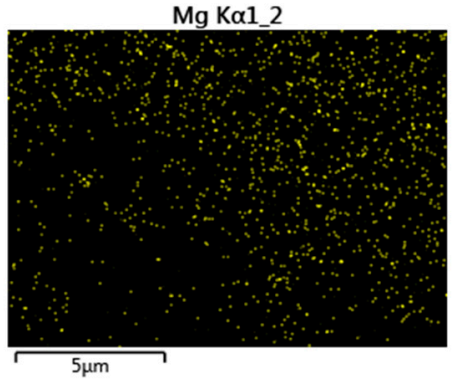

(c)

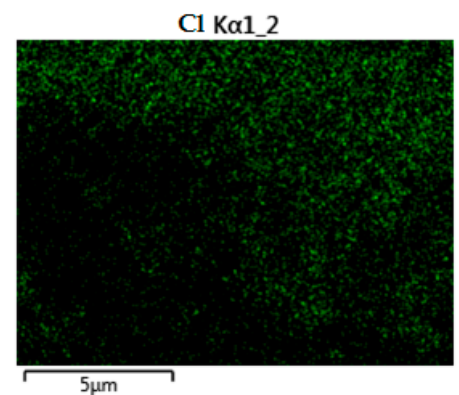

(f)

Figure 4. EDX maps of elemental distribution for the limestone filler: (a) EDX layered image, (b) Ca, (c) Mg, (d) O, (e) Si, and (f) $\mathrm{Cl}$. 


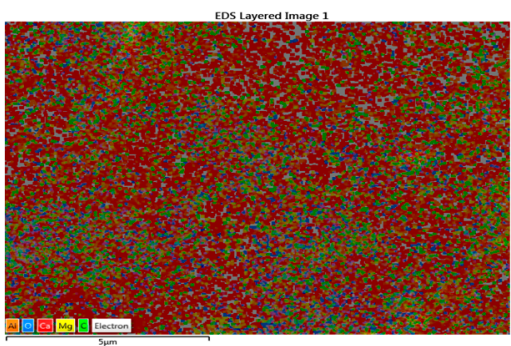

(a)

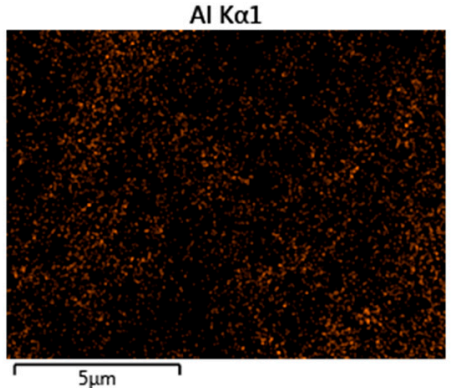

(d)

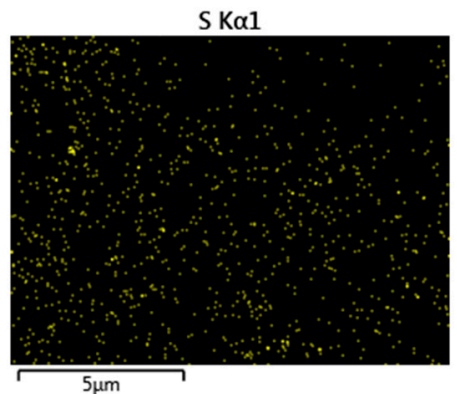

$(\mathrm{g})$

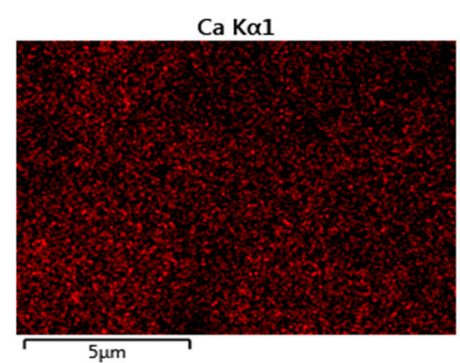

(b)

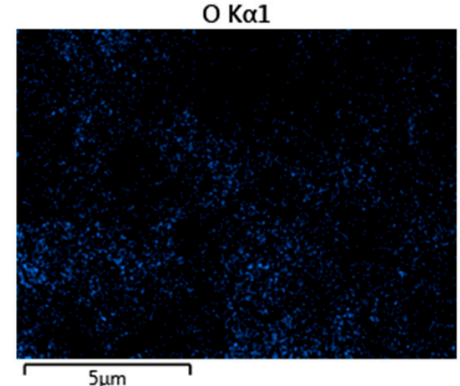

(e)

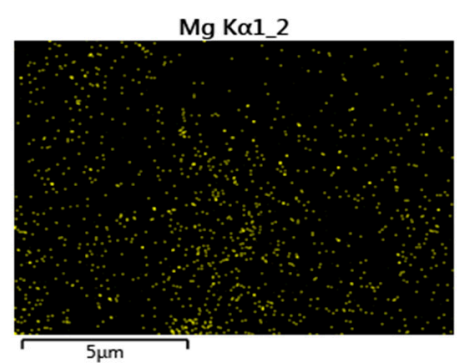

(c)

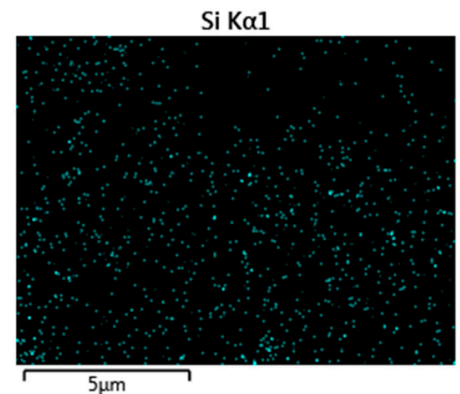

(f)

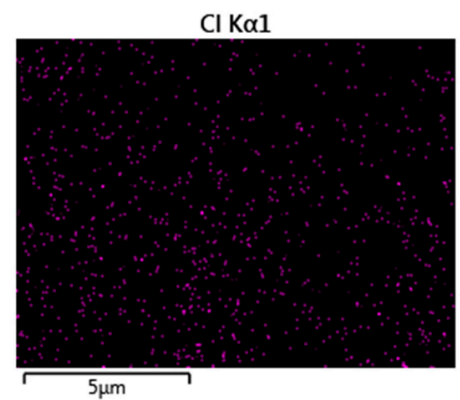

(h)

Figure 5. EDX maps of elemental distribution for the soda sludge filler: (a) EDX layered image, (b) Ca, (c) $\mathrm{Mg}$, (d) $\mathrm{Al}$, (e) O, (f) $\mathrm{Si},(\mathbf{g}) \mathrm{S}$, and (h) $\mathrm{Cl}$.

The EDX chemical analysis demonstrated a relatively heterogeneous elemental distribution in the case of the standard limestone filler, while for the soda sludge filler the components were quite uniformly distributed.

\subsection{Geometrical and Physical Characteristics}

Size Distribution

The results obtained after laboratory testing on natural and all industrial wastes are given in Table 1.

According to the standard SR EN 13043:2003, the upper and lower limits were imposed [1], meaning that a minimum $70 \%$ of particles must pass through a $63 \mu \mathrm{m}$ sieve and a minimum $85 \%$ particles must pass through $0.125 \mathrm{~mm}$ sieve, as dictated by the standard. The soda sludge filler shows a reduced fineness with approximately $8.5 \%$ compared with the lower limit; the same behavior is presented on the $0.125 \mathrm{~mm}$ sieve where the filler shows a reduced fineness with approximately $1 \%$ compared with the upper limit. In the same time, the calcium sulfate filler shows an improved fineness; the particles of this filler passed through all the sieves utilized in this test method. 
Table 1. Particle size distribution.

\begin{tabular}{|c|c|c|c|c|}
\hline $\begin{array}{c}\text { Sieves } \\
\text { Size }\end{array}$ & $\begin{array}{c}\text { Mass of } \\
\text { Material that } \\
\text { Remains on the } \\
\text { Sieve }\end{array}$ & $\begin{array}{l}\text { Percentage of } \\
\text { Material that } \\
\text { Remains on the } \\
\text { Sieve }\end{array}$ & $\begin{array}{c}\text { Total Percentage } \\
\text { of the Material } \\
\text { Passing through } \\
\text { the Sieve }\end{array}$ & $\begin{array}{l}\text { Lower and Upper } \\
\text { Limits According to } \\
\text { SR EN 13043: } 2003 \\
\text { and AND 605:2016 }\end{array}$ \\
\hline \multicolumn{5}{|c|}{ Limestone filler } \\
\hline $\mathrm{mm}$ & $\mathrm{g}$ & $\%$ & $\%$ & $\%$ \\
\hline 2 & 0 & 0 & 100 & 100 \\
\hline 0.125 & 3 & 6 & 94 & 85-100 \\
\hline 0.063 & 10.3 & 20.6 & 79 & 70-100 \\
\hline \multicolumn{5}{|c|}{ Soda sludge filler } \\
\hline $\mathrm{mm}$ & $\mathrm{g}$ & $\%$ & $\%$ & $\%$ \\
\hline 2 & 0 & 0 & 100 & 100 \\
\hline 0.125 & 8 & 16 & 84 & $85-100$ \\
\hline 0.063 & 18.1 & 36.2 & 64 & 70-100 \\
\hline \multicolumn{5}{|c|}{ Calcium sulfate filler } \\
\hline $\mathrm{mm}$ & $\mathrm{g}$ & $\%$ & $\%$ & $\%$ \\
\hline 2 & 0 & 0 & 100 & 100 \\
\hline 0.125 & 0 & 0 & 100 & $85-100$ \\
\hline 0.063 & 0.1 & 0.2 & 100 & 70-100 \\
\hline \multicolumn{5}{|c|}{ Fly ash with $10 \%$ lime filler } \\
\hline $\mathrm{mm}$ & $\mathrm{g}$ & $\%$ & $\%$ & $\%$ \\
\hline 2 & 0 & 0 & 100 & 100 \\
\hline 0.125 & 2.5 & 5 & 95 & $85-100$ \\
\hline 0.063 & 10.1 & 20 & 80 & 70-100 \\
\hline \multicolumn{5}{|c|}{ Fly ash filler } \\
\hline $\mathrm{mm}$ & $\mathrm{g}$ & $\%$ & $\%$ & $\%$ \\
\hline 2 & 0 & 0 & 100 & 100 \\
\hline 0.125 & 5 & 10 & 90 & $85 \ldots 100$ \\
\hline 0.063 & 13.3 & 26.6 & 73 & $70 \ldots 100$ \\
\hline
\end{tabular}

According to Jon Epps (2003), Kim Yong-Rak (2012), and Pasadin (2020), it was proven that a coarse filler added to asphalt mixtures does not fulfill its complex role, and a too fine filler leads to significant increase in binder consumption, thus making it difficult to homogenize the mixture and to promote the acceleration of the aging binder. They stated that the water resistance of asphalt mixtures could be improved by using fly ash as mineral filler [61,62].

Seventeen powders were evaluated through physicomechanical laboratory tests to determine which is the perfect combination that can be utilized in asphaltic mixture composition. To verify the possibility of replacing the natural filler (limestone) with these industrial wastes, every filler was tested in various dosages and combinations, as follows: the replacement of $100 \%$ limestone in asphalt mixtures using $30,50,70$ and $100 \%$ soda sludge, calcium sulfate, fly ash, and fly ash with $10 \%$ lime.

The evaluation of the volumetric mass and the Blaine specific surface is presented in Figure 6 for all the filler combinations presented above. 


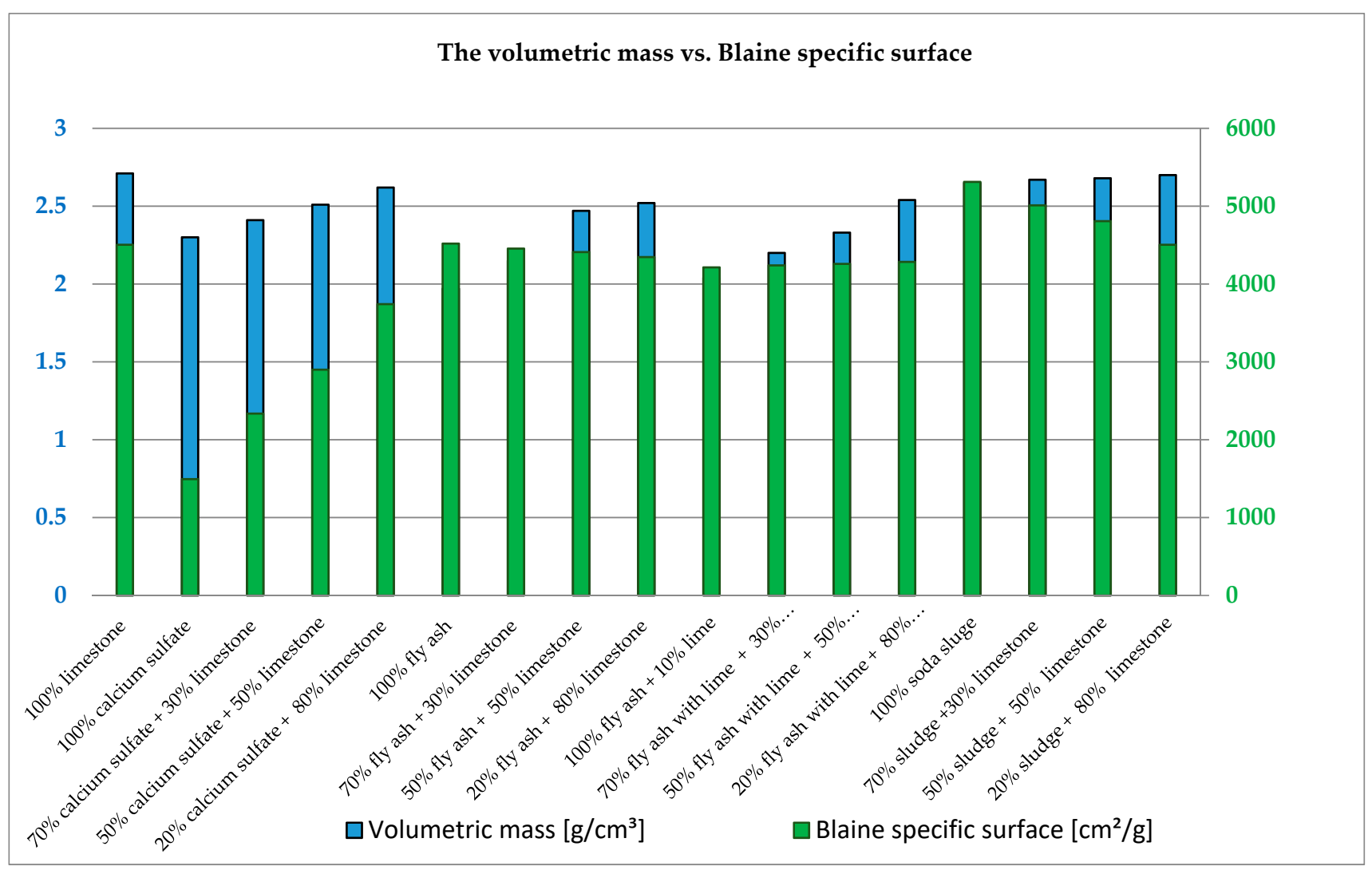

Figure 6. The volumetric mass and the Blaine specific surface of the mineral and artificial filler.

The particle size, or the fineness of powder materials, is very often critical to their performance. The volumetric mass of the industrial waste fillers can be easily compared with the volumetric mass of a standard filler. This property has a very small influence on all the combinations evaluated (i.e., the industrial waste utilized in asphaltic mixture composition) because of the very close results of the tests, with the exception of the $100 \%$ calcium sulfate, which has a specific surface lower than that of the limestone filler with $33 \%$. This property can influence and affect the quantity of bitumen and the mastic rigidity in asphaltic mixture compositions.

In line with the range set out in [1], all analyzed fillers have geometric characteristics for the maximum number of particles greater than $63 \mu \mathrm{m}$, except soda sludge filler, which shows a higher fineness in this case. The fillers' homogenous particle size distribution has an increased impact on the mastic viscosity and the rutting resistance of the asphaltic mixtures in which they will be used. The particle size and its shape were also verified by the SEM and EDX analyses; these two characteristics of the fillers can influence and affect the mechanical properties of the asphaltic mixtures. Apart from this, the SEM and EDX analyses suggest that the limestone filler and soda sludge filler show similarity in composition and aspect, Figure 7. 


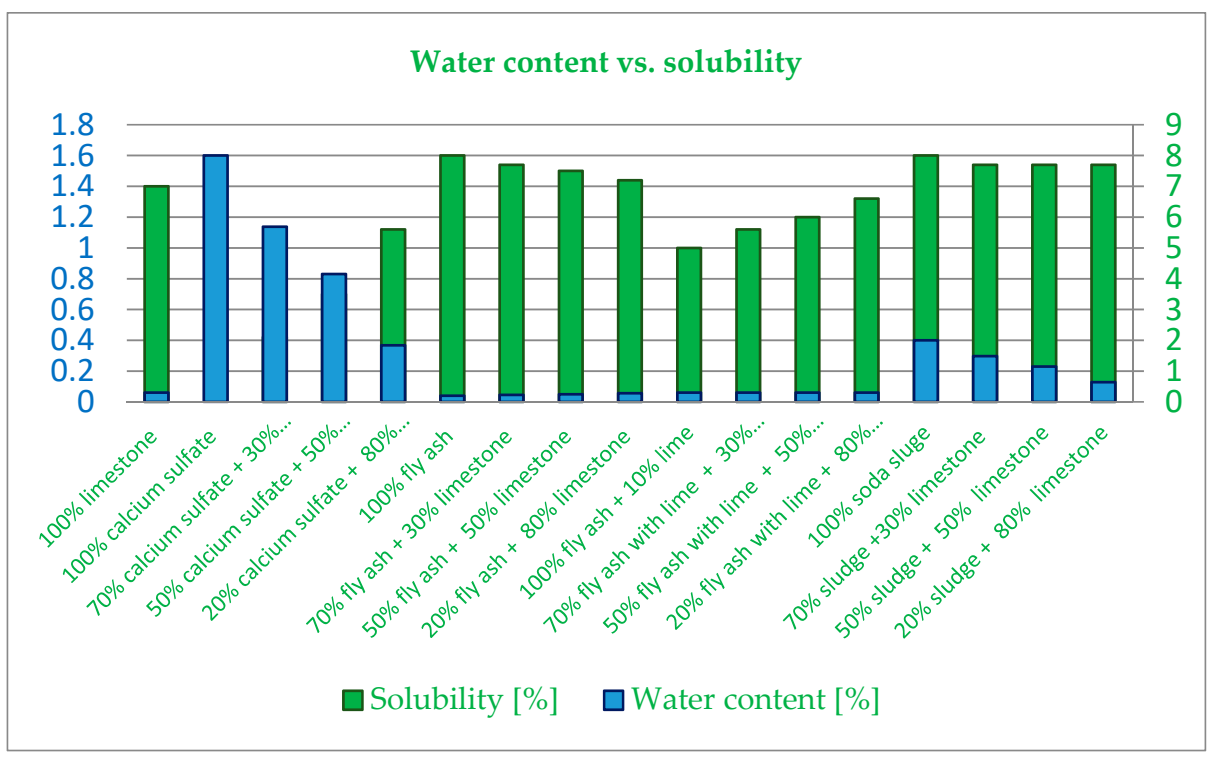

Figure 7. The water content and the solubility of the mineral and artificial filler.

The water content of limestone filler is only comparable with the fly ash filler and the fly ash with lime powder, while the calcium sulfate and soda sludge fillers are above the values mentioned in regulation standard [1]. As already known, it is necessary to evaluate and control the humidity. This involves drying the filler before using it in asphalt production plants. Based on the water content percentages by mass, limestone, fly ash, and fly ash with limestone fillers belong to the category $\mathrm{WC}_{1}$ (the usual category, with water content under $1 \%$ ), while for the soda sludge and calcium sulfate filler, the values were found to be higher than $1 \%$ water content by mass.

Calcium sulfate proved to exhibit a special behavior, as well as the soda sludge filler, in that they had values that are higher than the maximum limit found in [1]. The test results highlighted that all the evaluated waste powders can be utilized as a valid alternative to natural filler in asphalt mixtures, but special attention should be given to storage conditions, i.e., the time and money spend for drying the filler before using it.

The water solubility result has only one exception of the rule, namely the calcium sulfate filler, which is not soluble in water; this response is certainly linked to the chemical composition of the material. The results of the water solubility test confirmed that the filler belong to the $\mathrm{WS}_{10}$ category (water solubility under 10\%), in accordance with [1], Figure 8.

The porosity of the industrial waste fillers test shows a high number of intergranular voids for the utilization of $100 \%$ fly ash, fly ash with lime, soda sludge, or calcium sulfate. Once limestone is added to composition, the values come to the limits highlighted for fillers that are often used in the production of asphaltic mixtures.

The stiffening properties of all industrial waste powders were evaluated according to the voids of dry compacted filler. The results obtained by laboratory tests correspond to the following categories according to [1]: the limestone belongs to the $V_{28 / 38}$ category (the lower category, involving fewer voids in powder); all industrial waste powders in $20-80 \%$ composition with limestone filler belong to the $\mathrm{V}_{28 / 45}$ composition category (representing a higher number of voids); $100 \%$ fly ash, fly ash with lime, and soda sludge belong to the $\mathrm{V}_{44 / 45}$ category (reaching the maximum limit of voids in powder). These are all presented in Table 2. 


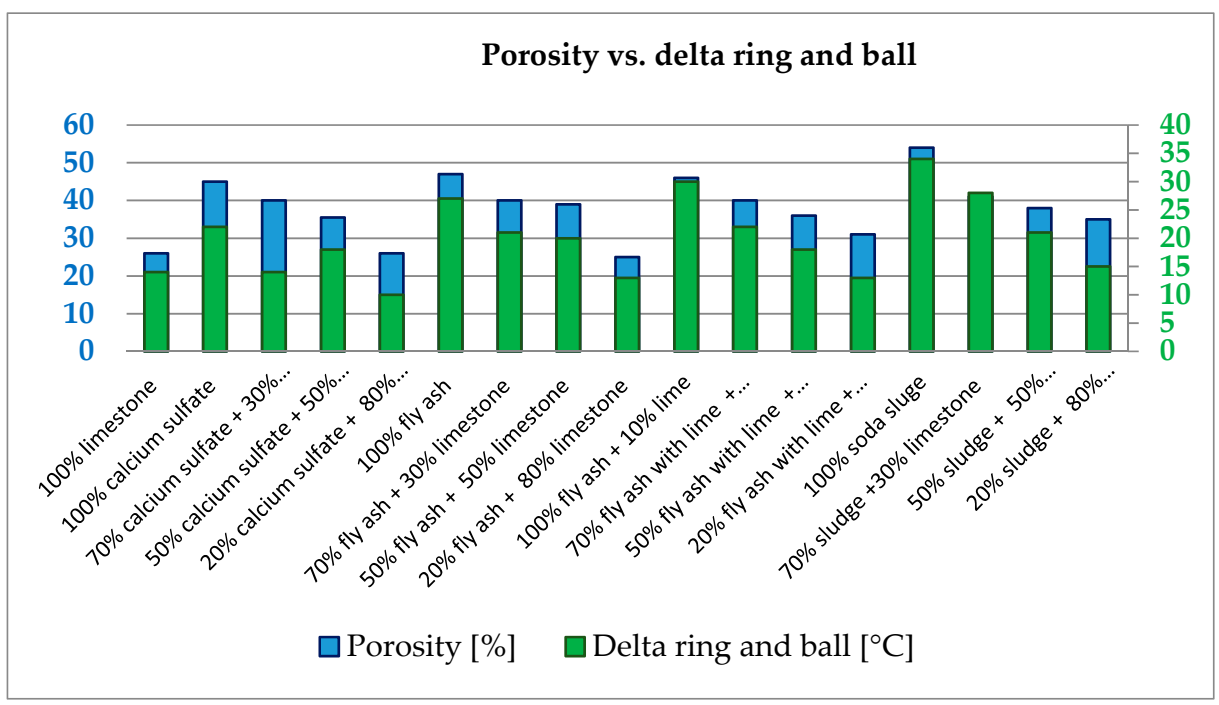

Figure 8. The porosity and the delta ring and ball of the mineral and artificial filler.

Table 2. Categories for voids of dry compacted filler.

\begin{tabular}{cc}
\hline Voids of Dry Compacted Filler & Category \\
\hline $100 \%$ limestone & V28/38 \\
$100 \%$ fly ash & \\
$100 \%$ fly ash with lime & $\mathrm{V} 44 / 45$ \\
$100 \%$ soda sludge & \\
$20-100 \%$ calcium sulfate & \\
$20-80 \%$ fly ash & $\mathrm{V} 28 / 45$ \\
$20-80 \%$ fly ash with lime & \\
$20-80 \%$ soda sludge & \\
\hline
\end{tabular}

According to the obtained results, all industrial waste fillers show a higher porosity compared with limestone filler. The softening point represents the temperature at which the tested material under standardized test conditions attains a specific consistency. The delta ring and ball of the evaluated industrial waste fillers corresponds to the results of the relevant categories stated in Table 3, in accordance with [1].

Table 3. Categories for delta ring and ball.

\begin{tabular}{cc}
\hline Delta Ring and Ball $\left({ }^{\circ} \mathbf{C}\right)$ & $\begin{array}{c}\text { Category } \\
\Delta_{\mathbf{R} \& \mathbf{B}}\end{array}$ \\
\hline $100 \%$ limestone & $\Delta_{\mathrm{R} \& \mathrm{~B}} 8 / 16$ \\
$100 \%$ fly ash & \\
$100 \%$ fly ash with lime & $\Delta_{\mathrm{R} \& \mathrm{~B}} 25$ \\
$70 \%$ and $100 \%$ soda sludge & \\
$20-100 \%$ calcium sulfate & \\
$20-80 \%$ fly ash & $\Delta_{\mathrm{R} \& \mathrm{~B}} 8 / 25$ \\
$20-80 \%$ fly ash with lime & \\
$20-80 \%$ soda sludge & \\
\hline
\end{tabular}

Some relationships may be present between the ring and ball temperature and the porosity of the fillers. The higher porousness and also the stiffening properties of industrial waste fillers compared with the limestone filler can cause a hardening of bituminous mastic, with implications in the bitumen dosage in the asphalt mixture compositions and also in the durability of asphaltic mixture. It was demonstrated that fillers with a higher porosity show a high softening temperature, leading to a harder mastic. This characteristic can be seen as a negative impact on the workability of the asphaltic mixture. Methylene blue 
tests did verify that the compositions comply with the regulations of the imposed standard conditions; this means that the industrial wastes will not have a negative effect of fine particles on the characteristics of the asphaltic mixtures, Figure 9.

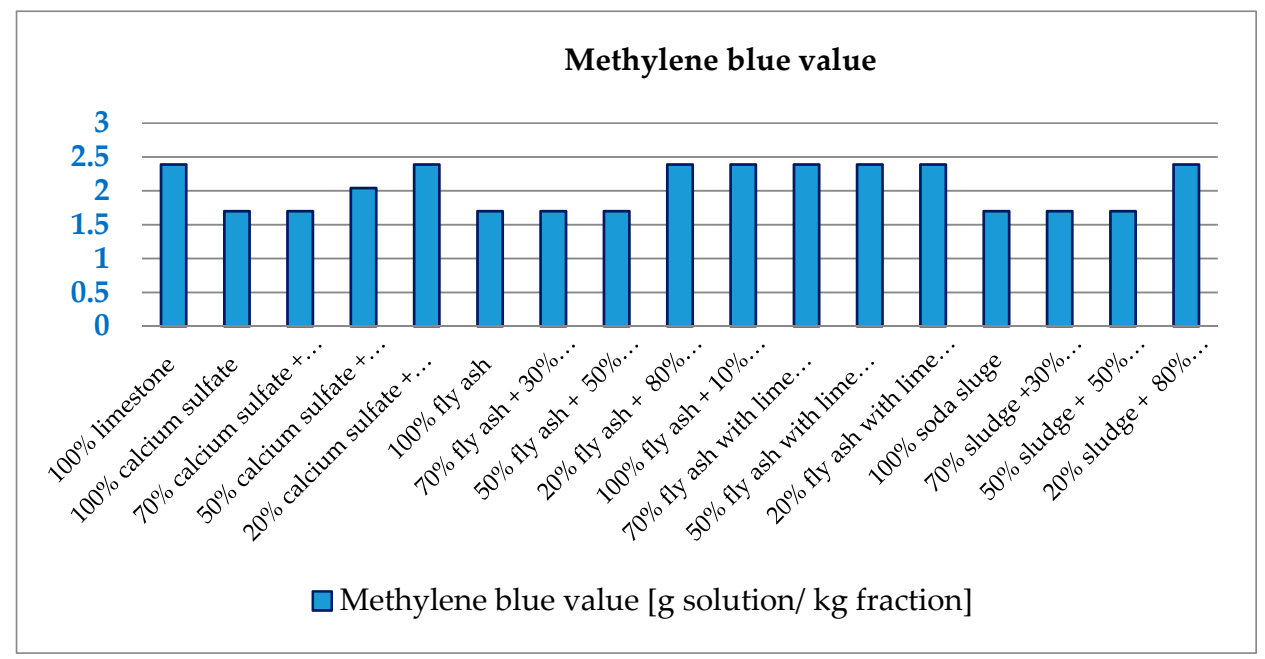

Figure 9. The methylene blue value and the volumetric mass of the mineral and artificial filler.

The harmful fines (e.g., swelling clay) were determined, and the maximum methylene blue $\left(\mathrm{MB}_{\mathrm{F}}\right)$ values measured for the fillers correspond to the category $\mathrm{MB}_{\mathrm{F}} 7$ for all the evaluated powders, according to [1]. This category means that all industrial wastes can replace the natural filler, as their behaviors were shown to be extremely close to that of the control filler. For each test, all the results are presented with average values of minimum three repetitions.

One possible future research direction is highlighted by the necessity to evaluate the interaction that occurs in the asphaltic mixture composition of these fillers, in order to determine the best dosage that can be utilized while also evaluating the interaction of the aggregates and bitumen. Another research direction that can be mentioned is the evaluation of the benefits of using industrial waste in asphaltic mixtures by the economic benefits of using them. Still another direction of study can involve tests with different types of bitumen to discover whether there is a real relationship between the porosity and the stiffening properties of the powders with the rigidity of the mastic.

\section{Conclusions}

The present preliminary study reports a wide range of morphological, chemical, geometrical, and physical characteristics of industrial waste materials, comparing them with limestone filler as the control filler. The results from the performance tests can be summarized as follows:

- The SEM and EDX chemical analyses present very important information, showing the similarities between the components and also in the distribution of all components in the soda sludge powder and the limestone filler. This important characteristic have a crucial role in time preparation and mixing, giving homogeneity to the composition of asphalt mixture.

- The EDS tests verified the presence of low quantities of silicon dioxide $\left(\mathrm{SiO}_{2}\right)$ in the chemical composition of tested fillers. At the same time, the presence of calcium (Ca) is favorable, due to its good interaction with bitumen.

- According to the particle size distribution test results, we found that the calcium sulfate filler and the soda sludge filler can have an important role in the viscosity of asphaltic mixture composition, while the behavior of fly ash is similar with that of the control filler. 
- The water content of limestone filler is comparable to the fly ash filler, but at the same time, the values of both the calcium sulfate filler and soda sludge fillers are above the values listed in SR EN 13043. Their water content values are influenced by the exposure to an environment with humidity during the storage process. It is highly recommended that humidity should be controlled in order to ensure that the process is correct for asphalt production in plants.

- The use of filler improves the passive adhesion between the aggregates and the bitumen, leading to asphaltic mixtures with higher water resistance and thus higher durability. The porosity and also delta ring and ball tests show higher results compared with conventional filler, and these characteristics needs to be evaluated very closely in an asphaltic mixture composition.

The laboratory evaluation suggests that in all the tests, industrial waste materials may be considered as a valid alternative to natural filler in asphalt mixture composition. Some results, however, do not meet the standard requirements suggested for natural filler. The filler characteristics and proportions that directly affect the performance of the final asphaltic mixture can be assessed by future developments and studies.

The necessity of testing and declaring all properties specified in this study for the evaluated industrial waste powders should be considered a big step in improving our ability to apply reusable artificial materials and to protect nonrenewable materials. Hence, a complete economic evaluation should be executed to affirm the feasibleness of employing HMAs incorporating different types of industrial waste powders.

Author Contributions: Conceptualization, C.D. and A.B.; methodology, C.D.; validation, A.B.; formal analysis, A.B.; investigation, C.D. and A.B.; resources, A.B.; data curation, C.D.; writing-original draft preparation, C.D.; writing—review and editing, A.B.; visualization, C.D.; supervision, A.B. All authors have read and agreed to the published version of the manuscript.

Funding: This research received no external funding.

Institutional Review Board Statement: Not applicable.

Informed Consent Statement: Not applicable.

Data Availability Statement: No new data were created or analyzed in this study. Data sharing is not applicable to this article.

Acknowledgments: The authors appreciate the help and support of Andreea Florea with the interpretation of industrial wastes chemical characterization. The authors also acknowledge the Centre for Surface Science and Nanotechnology at University Politehnica of Bucharest for SEM-EDX facilities.

Conflicts of Interest: The authors declare no conflict of interest.

\section{References}

1. European Standard SR EN 13043:2003/AC:2004-Aggregates for Bituminous Mixtures and Surface Treatments for Roads, Airfields and Other Trafficked Areas; European Committee for Standardization: Brussels, Belgium, 2013.

2. Bocci, M.; Giuliani, F. Caratterizzazione di filler per conglomerati bituminosi. In Proceedings of the XXIII Convegno Nazionale Stradale AIPCR, Verona, Italy, 1 January 1998; pp. 18-21.

3. Kandhal, P.S.; Parker, F. Aggregate Tests Related to Asphalt Concrete Performance in Pavements; NCHRP Report 405; National Academy Press: Washington, DC, USA, 1998.

4. Grabowski, W.; Wilanowicz, J. The structure of mineral filler and their stiffening properties in filler bitumen mastics. Mater. Struct. 2008, 41, 793-804. [CrossRef]

5. Harris, B.M.; Stuart, K.D. Analysis of Mineral Filler and Mastics Used in Stone Matrix Asphalt. In Proceedings of the Association of Asphalt Paving Technologist (AAPT), Portland, OR, USA, 27-29 March 1995; Volume 64, pp. $27-29$.

6. Huang, B.; Shu, X.; Chen, X. Effect of mineral fillers on hot-mix aboratory measured properties. Int. J. Pavement Eng. 2007, 8, 1-9. [CrossRef]

7. Zulkati, A.; Diew, W.Y.; Delai, D.S. Effects of fillers on properties of asphalt-concrete mixture. J. Transp. Eng. 2012, 138, 902-910. [CrossRef]

8. Pasadin, A.R.; Perez, I. The influence of the mineral filler on the adhesion between aggregates and bitumen. Int. J. Adhes. Adhes. 2015, 58, 53-58. [CrossRef] 
9. Alvarez, A.E.; Ovalles, E.; Caro, S. Assessment of the effect of mineral filler on asphalt-aggregate interfaces based on thermodynamic properties. Constr. Build. Mater. 2012, 28, 599-606. [CrossRef]

10. Little, D.N.; Petersen, J.C. Unique effects of hydrated lime filler on the performance-related properties of asphalt cements: Physical and chemical interactions revisited. J. Mater. Civ. Eng. 2005, 17, 207-218. [CrossRef]

11. Dondi, G.; Mazzotta, F.; Sangiorgi, C.; Pettinari, M.; Simone, A.; Vignali, V.; Tataranni, P. Influence of cement and limestone filler on the rheological properties of mastic in cold bituminous recycled mixtures. In Proceedings of the 3rd International Conference on Trasportation Infrastructures (ICTI 2014), Pisa, Italy, 22-25 April 2014; pp. 22-25.

12. Davis, C.; Castorena, C. Implications of physicoechemical interactions in asphalt mastics on asphalt microstructure. Constr. Build. Mater. 2015, 94, 83-89. [CrossRef]

13. Cheng, Y.; Tao, J.; Jiao, Y.; Tan, G.; Guo, Q.; Wang, S.; Ni, P. Influence of the properties of filler on high and medium temperature performances of asphalt mastic. Constr. Build. Mater. 2016, 118, 268-275. [CrossRef]

14. Dong, Z.; Liu, Z.; Wanga, P.; Gong, X. Nanostructure characterization of asphalt-aggregate interface through molecular dynamics simulation and atomic force microscopy. Fuel 2017, 189, 155-163. [CrossRef]

15. Choudhary, J.; Kumar, B.; Gupta, A. Effect of filler on the bitumen-aggregate adhesion in asphalt mix. Int. J. Pavement Eng. 2018, 21, 1-9. [CrossRef]

16. Antunes, V.; Freire, A.C.; Quaresma, L.; Micaelo, R. Effect of the chemical composition of fillers in the filler-bitumen interaction. Constr. Build. Mater. 2016, 104, 85-91. [CrossRef]

17. Modarres, A.; Bengar, P.A. Investigating the indirect tensile stiffness, toughness and fatigue life of hot mix asphalt containing copper slag powder. Int. J. Pavement Eng. 2017. [CrossRef]

18. Burlacu, A.; Răcănel, C. Reducing cost of infrastructure works using new technologies. In Proceedings of the 3rd International Conference on Road and Rail Infrastructure-CETRA, Dubrovnik, Split, 28-30 April 2014; pp. 189-194.

19. Choudhary, J.; Kumar, B.; Gupta, A. Utilization of solid waste materials as alternative fillers in asphalt mixes: A review. Constr. Build. Mater. 2020, 234, 117271. [CrossRef]

20. Matos, P.; Micaelo, R.; Duarte, C.; Quaresma, L. Influence of bitumen and filler on the selection of appropriate mixing and compaction temperatures. Int. J. Pavement Res. Technol. 2014, 7, 237-246.

21. Micaelo, R.; Ribeiro, J.; Azevedo, M.; Azevedo, N. Asphalt compaction study: Micromechanical modelling of a simplified lab compaction procedure. Road Mater. Pavement Des. 2011, 12, 461-491. [CrossRef]

22. Sangiorgi, C.; Tataranni, P.; Mazzotta, F.; Simone, A.; Vignali, V.; Lantieri, C. Alternative fillers for the production of bituminous mixtures: A screening investigation on waste powders. Coatings 2017, 7, 76. [CrossRef]

23. Simone, A.; Mazzotta, F.; Eskandarsefat, F.; Sangiorgi, C.; Vignali, V.; Lantieri, C.; Dondi, G. Experimental application of waste glass powder filler in recycled dense-graded asphalt mixtures. Road Mater. Pavement Des. 2019, 20, 592-607. [CrossRef]

24. Muniandy, R.; Aburkaba, E.; Taha, R. Effect of mineral filler type and particle size on the engineering properties of stone mastic asphalt pavements. J. Eng. Res. 2013, 10, 13-32. [CrossRef]

25. Chen, M.; Lin, J.; Wu, S. Potential of recycled fine aggregates powder as filler in asphalt mixture. Constr. Build. Mater. 2011, 25, 3909-3914. [CrossRef]

26. Ekblad, J.; Lundström, R.; Simonsen, E. Water susceptibility of asphalt mixtures as influenced by hydraulically active fillers. Mater. Struct. 2015, 48, 1135-1147. [CrossRef]

27. Androjić, I.; Dimter, S. Properties of hot mix asphalt with substituted waste glass. Mater. Struct. 2016, 49, 249-259. [CrossRef]

28. Chen, M.; Lin, J.; Wu, S.; Liu, C. Utilization of recycled brick powder as alternative filler in asphalt mixture. Constr. Build. Mater. 2011, 25, 1532-1536. [CrossRef]

29. Al-Hdabi, A. Laboratory investigation on the properties of asphalt concrete mixture with Rice Husk Ash as filler. Constr. Build. Mater. 2016, 126, 544-551. [CrossRef]

30. Modarres, A.; Rahmanzadeh, M. Application of coal waste powder as filler in hot mix asphalt. Constr. Build. Mater. 2016, 66, 476-483. [CrossRef]

31. Azzam, M.O.; Al-Ghazawi, Z. Evaluation of incorporating oil shale filler aggregate into hot mix asphalt using Superpave mix design. Constr. Build. Mater. 2015, 10, 359-379. [CrossRef]

32. Sangiorgi, C.; Tataranni, P.; Simone, A.; Vignali, V.; Lantieri, C.; Dondi, G. Assessment of waste bleaching clay as alternative filler for the production of porous asphalts. Constr. Build. Mater. 2016, 109, 1-7. [CrossRef]

33. Pasandin, A.R.; Perez, I.; Ramırez, A.; Cano, M.M. Moisture damage resistance of hot-mix asphalt made with paper industry wastes as filler. J. Clean. Prod. 2016, 112, 853-862. [CrossRef]

34. Do, H.S.; Mun, P.H.; Keun, R.S. A study on engineering characteristics of asphalt concrete using filler with recycled waste lime. Waste Manag. 2008, 28, 191-199.

35. Katamine, N.M. Phosphate waste in mixtures to improve their deformation. J. Transp. Eng. 2000, 126, 382-389. [CrossRef]

36. Yongjie, X.; Haobo, H.; Shujing, Z.; Jin, Z. Utilization of municipal solid waste incineration ash in stone mastic asphalt mixture: Pavement performance and environmental impact. Constr. Build. Mater. 2009, 23, 989-996.

37. Rutkowska, G.; Wichowski, P.; Fronczyk, J.; Franus, M.; Chalecki, M. Use of fly ashes from municipal sewage soda sludge combustion in production of ash concretes. Constr. Build. Mater. 2018, 188, 874-883. [CrossRef]

38. Suchorab, Z.; Barnat-Hunek, D.; Franus, M.; Łagód, G. Mechanical and physical properties of hydrophobized lightweight Aggregate concrete with sewage soda sludge. Materials 2016, 9, 317. [CrossRef] 
39. Deng-Fong, L.; Jyh-Dong, L.; Shun-Hsing, C. The application of baghouse fines in Taiwan. Resour. Conserv. Recycl. 2006, 46, 281-301.

40. Ibrahim, A.; Assa'ad, A. Effect of Jordanian oil shale fly ash on asphalt mixes. J. Mater. Civ. Eng. 2005, 17, 553-559.

41. Baoshan, H.; Qiao, D.; Burdette, E.G. Laboratory evaluation of incorporating waste ceramic materials into Portland cement and asphaltic concrete. Constr. Build. Mater. 2009, 23, 3451-3456.

42. Bilgin, N.; Yeprem, H.A.; Arslan, S.; Bilgin, A.; Gunay, E.; Marşoglu, M. Use of waste marble powder in brick industry. Constr. Build. Mater. 2012, 29, 449-457. [CrossRef]

43. Karasahin, M.; Terzi, S. Evaluation of marble waste dust in the mixture of asphaltic concrete. J. Sci. Direct. 2007, 21, 616-620. [CrossRef]

44. West, R.C.; James, R.S. Evaluation of a lime kiln dust as a mineral filler for stone matrix asphalt. In Proceedings of the 85th Annual Meeting of the Transportation Research Board, Washington, DC, USA, 22-26 January 2008.

45. Tuncan, M.; Tuncan, A.; Cetin, A. The use of waste materials in asphalt concrete mixtures. J. Waste Manag. Res. 2005, 23, 550-559. [CrossRef]

46. Punyaslok, R.; Joshua, E.L.; William, G.B.; Henrique, R. Performance analysis of asphalt mixtures modified with ground tire rubber modifiers and recycled materials. Sustainability 2019, 11, 1792. [CrossRef]

47. Racanel, C.; Burlacu, A. Using crumb rubber in warm asphalt concrete. In Proceedings of the 15th Geo Conference-“'International Multidisciplinary Scientific Geo Conference SGEM", Albena, Bulgaria, 18-24 June 2015; pp. 795-802. [CrossRef]

48. Diab, A.; Enieb, M. Investigating influence of mineral filler at asphalt mixture and mastic scales. Int. J. Pavement Res. Technol. 2018, 11, 213-224. [CrossRef]

49. Lesueur, D.; Teixeira, A.; Lazaro, M.M.; Andaluz, D.; Ruiz, A. A simple test method in order to assess the effect of mineral fillers on bitumen ageing. Constr. Build. Mater. 2016, 117, 182-189. [CrossRef]

50. European Standard SR EN 933-10:2009-Tests for Geometrical Properties of Aggregates Assessment of Fines. Grading of Filler Aggregates (Air Jet Sieving); European Committee for Standardization: Brussels, Belgium, 2009.

51. European Standard SR EN 1097-5:2008-Tests for Mechanical and Physical Properties of Aggregates Determination of the Water Content by Drying in a Ventilated Oven; European Committee for Standardization: Brussels, Belgium, 2008.

52. European Standard SR EN 1097-7:2001-Test for Mechanical and Physical Properties of Aggregates. Part 7: Determination of the Particle Density of Filler-Pycnometer Method; European Committee for Standardization: Brussels, Belgium, 2001.

53. European Standard SR EN 933-9+A1:2013-Tests for Geometrical Properties of Aggregates Assessment of Fines. Methylene Blue Test; European Committee for Standardization: Brussels, Belgium, 2013.

54. European Standard SR EN 1097-4:2001-Test for Mechanical and Physical Properties of Aggregates. Part 4: Determination of the Voids of Dry Compacted Filler; European Committee for Standardization: Brussels, Belgium, 2001.

55. European Standard SR EN 1427:2007—Bitumen and Bituminous Binders—Determination of the Softening Point—Ring and Ball Method; European Committee for Standardization: Brussels, Belgium, 2007.

56. European Standard SR EN 13179-1:2013-Tests for Filler Aggregate Used in Bituminous Mixtures-Part 1: Delta Ring and Ball Test; European Committee for Standardization: Brussels, Belgium, 2013.

57. European Standard SR EN 196-6:2010-Methods of Testing Cement. Part 6: Determination of Fineness; European Committee for Standardization: Brussels, Belgium, 2010.

58. Ashfaq, M.Y.; Al-Ghouti, M.A.; Al Disi, Z.A.; Zouari, N. Investigating the microorganisms-calcium sulfate interaction in reverse osmosis systems using SEM-EDX technique. J. Environ. Chem. Eng. 2020, 8, 103963. [CrossRef]

59. Blissett, R.; Rowson, N. A review of the multi-component utilisation of coal fly ash. Fuel 2012, 97, 1-23. [CrossRef]

60. Assi, A.; Bilo, F.; Zanoletti, A.; Ponti, J.; Valsesia, A.; La Spina, R.; Depero, L.E.; Bontempi, E. Review of the reuse possibilities concerning ash residues from thermal process in a medium-sized urban system in Northern Italy. Sustainability 2020, $12,4193$. [CrossRef]

61. Yong-Rak, K.; Ingrid, P.; Seong-Wan, P. Experimental evaluation of anti- stripping additives in bituminous mixtures through multiple scale laboratory test results. Constr. Build. Mater. 2012, 29, 383-393. [CrossRef]

62. Epps, J.; Berger, E.; Anagnos, J.N. Treatments. In Proceedings of the National Seminar on Moisture Sensitivity of Asphalt Pavements, San Diego, CA, USA, 4-6 February 2003. 